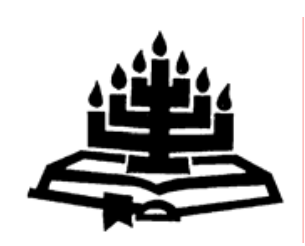

\title{
Basisteoretiese grondslae van die seën in die erediens en voortvloeiende riglyne vir die liturgie
}

\author{
Ben de Klerk \\ Skool vir Kerkwetenskappe \\ Potchefstroomkampus \\ Noordwes-Universiteit \\ POTCHEFSTROOM \\ E-pos: Ben.deklerk@nwu.ac.za
}

\begin{abstract}
Basic-theoretical foundations of the blessing in the worship service and ensuing guidelines for the liturgy
\end{abstract}

The Biblical foundations of the blessing in the church service and the meaning and function of the salutatory and sendingaway blessings are the focus of this article. A short extract from history follows, and based on findings from Scripture and history, theoretical perspectives for practice and liturgical guidelines are indicated. Some of the most important conclusions drawn are the following: The congregation of Jesus Christ should receive the blessing of the Lord as indispensable gift in its assemblage. Without this blessing communion with God and each other, trust in God and fulfilment of each believer's vocation in the world are impossible. The salutatory blessing pours out onto the congregation all the blessings that enable members to participate to advantage in the church service. The congregation is blessed and sent back into the world by God himself. Without the sending-away blessing the congregation cannot fulfil its vocation in the world, especially to be witnesses for Christ. If an ordained minister of the gospel is present in the gathering of the congregation he should pronounce the blessing, which comes directly from God. It is vital that the congregation appropriate the blessing in faith by means of an overt act, namely by saying "amen" to that. 


\section{Opsomming}

\section{Basisteoretiese grondslae van die seën in die erediens en voortvloeiende riglyne vir die liturgie}

Die Bybelse grondslae van die seën in die erediens en die betekenis en funksie van die seëngroet en wegstuurseën is die fokus van hierdie artikel. 'n Kort snit uit die geskiedenis volg en vanuit die bevindings uit die Skrif en die geskiedenis word praktykteoretiese perspetiewe en liturgiese riglyne aangedui. Van die belangrikste bevindings waartoe gekom is, is die volgende: die gemeente van Jesus Christus moet in hulle samekoms die seën van die Here as onontbeerlike gawe ontvang. Sonder hierdie seën is gemeenskap met God en mekaar, geloofsvertroue en nakoming van elkeen se roeping in die wêreld nie moontlik nie. Die seëngroet stort al die gawes in die gemeente en stel lidmate in staat om vrugbaar aan die erediens te kan deelneem. Die gemeente is begenadig om deur God self in hulle leefwêreld teruggestuur te word deurdat Hy sy seën aan hulle toesê. Sonder die wegstuurseën kan die gemeente nie hulle roeping in die wêreld vervul nie - veral om getuies van Christus te wees. Waar 'n gevolmagtigde bedienaar van die Woord in die samekoms van die gemeente teenwoordig is, behoort hy die seën, wat regstreeks van God kom, af te kondig. Dit is noodsaaklik dat die gemeente die seën gelowig toeëien deur 'n aktiewe handeling, naamlik deur daarop "amen" te sê.

\section{Inleiding}

Daar is verskeie sienings van die rol en funksie van die seën in die erediens: in die algemene spreektaal word dikwels van die "aanvangseën" en die "slotseën" gepraat, só asof die erediens 'n statiese gebeurtenis is met ' $n$ begin en ' $n$ einde. Daarmee word die betekenis en funksie van die seën verskraal tot 'n handeling waarmee begin en geëindig word. Die woordjie seën is afgelei van die Latynse signum (teken). Oorspronklik kom die begrip van die Hebreeuse ברכ en het dit die betekenis van 'n begunstigde aan wie 'n guns, 'n genadegawe, verleen word (Van de Kamp, 1998:316). Die seën is 'n versekering wat die gemeente van Christus ontvang en dit word in die Bybelse Latyn benedictio en in Grieks eul ogia genoem. Die vraag wat in hierdie artikel aan die orde kom is die volgende: Wat is die Bybelse grondslae van die seën in die erediens en watter liturgiese riglyne kan daaruit afgelei word? Watter effek behoort die seën op die deelname aan die erediens en op die lewe van gelowiges ná die samekoms te hê? 
Dit is nodig om prinsipieël oor die Bybelse gegewens ten opsigte van die seën te besin. In hierdie artikel word aansluiting gevind by die model wat Zerfass (1974:166 e.v.) vir die Praktiese Teologie ontwerp het en 'n basisteorie word gevorm uit die teologiese tradisie. 'n Basisteorie stel bibliologies-dogmatiese en eties-normatiewe funderings. Basisteoreties word hoofsaaklik vanuit die Skrif gewerk en daar sal hierin van die grammaties-historiese eksegetiese-metode gebruik gemaak word (De Klerk \& Van Rensburg, 2005). Daaruit word dan aan die hand van Zerfass se genoemde metode 'n hermeneutiese proses gevolg wat lei tot 'n praktykteorie waaruit praktykteoretiese riglyne getrek word (Venter, 1993:247).

Die werkplan wat gevolg word, is om die grondslae van die seën vanuit die Ou Testament na te gaan, daarna kom Lukas 24:50-53 onder die soeklig. Die grondslae van die seëngroet en wegstuurseën word vanuit die betrokke Skrifgedeeltes ondersoek, enkele grepe uit die liturgiese geskiedenis kom aan die orde en uiteindelik word gepoog om praktykteoretiese perspektiewe en liturgiese riglyne daar te stel.

\section{Grondslae vanuit die Ou Testament}

\subsection{Waar alles begin: God seën Adam en Eva en Abram}

Reeds in die eerste hoofstuk van die Bybel word van God se seën gepraat. Nadat God die man en vrou geskape het, het Hy hulle geseën met die gawes wat hulle nodig gehad het om die skeppingsopdrag te kan uitvoer. $\mathrm{Na}$ die sondeval en die uiterste sonde van die toring van Babel het God 'n nuwe verbondsvolk in die lewe geroep met Abram as verbondshoof. Hy seën Abram tot só 'n mate dat Abram 'n seën sal wees vir ander en dat in Abram al die geslagte van die aarde geseën word (Gen. 12:1-3). In die Ou Testament is die seën méér as ' $n$ bede of ' $n$ wens. "Het is een concrete heilzame kracht, die leven geeft en het leven sterkt" (Van Leeuen, 1998:258).

\subsection{Die priesterlike seën}

Aäron en die priesters as amptelike verteenwoordigers van die Here kry die opdrag om die volk te seën (Lev. 9:22). Nadat hy die voorgeskrewe offers gebring het, word Aäron deur hierdie handelinge in sy amp as hoëpriester bevestig. Dan volg die grootse oomblik: hy hef sy hande op en lê die priesterlike seën op die volk. Hy maak vir die eerste keer gebruik van die uitsluitlike voorreg van die priesters om die volk te seën (Deut. 10:8; 27:14; Hartley, 1992:123). Deurdat 
Aäron en die priesters nou die volmag hiertoe van God amptelik ontvang het, laat hy met woorde wat regstreeks van God af kom, God se seën in die harte van die volk neerdaal (Calvin, 1958:245).

Vir ons beteken seën om iemand voorspoed toe te wens. Maar ברכ gaan uit van die gedagte dat deur middel van 'n sakramentele woordereeks iets ingedra word in iemand se lewensentrum. Die indra van die seën deur die toesegging daarvan laat die ontvanger se volle lewe verder ontplooi. Dit stel dus die persoon in staat tot 'n rykdom van lewensdade (Noordtzij, 1957:83). Die seën is so kragtig omdat dit bewerk wat dit aan die volk toesê (Gispen, 1950:159).

In the OT the root brk covers a wide range of ideas. It is commonly used to convey the idea of blessing, covering everything from creation and patriarchal blessings to priestly blessing/ benediction. Although the semantic range is wide for brk, it is agreed that the power of pronouncing blessings in Israel was especially vested in God's appointed agents, namely the priests. (Kapic, 2005:248.)

Die priesters het die taak gehad om die volk by die tempel te seën en dit is uitgespreek op die trappe van die "heilige". Seënspreuke is normaalweg uitgespreek in die heiligdom, óf wanneer die aanbidders inkom (vgl. Ps. 118:26) óf, meer algemeen, wanneer hulle vanaf die heiligdom weggestuur word (vgl. Lev. 9:22 e.v.; Davies, 1995: 67). Die tempelliturgie het naas sang, gebed, skuldbelydenis, skuldvergiffenis dus ook seëntoeseggings bevat. Só was dit ook in die Sinagogale liturgie (GKSA, 1985:400).

\subsection{Numeri 6 as grondslag vir die seënformule 1}

Die volk staan op die punt om van Sinaï te vertrek en met die seën van Numeri 6 bevestig die Here dat Hy saam met hulle sal trek. Daarom staan hierdie seën sentraal in die volk se voorbereidings voor hulle vertrek van Sinaï af (Num. 1:1-10:10). Moses word hier beveel om aan Aäron en sy seuns die vorm, struktuur en woorde van die seën wat hulle oor die volk moet afkondig, bekend te maak (Davies, 1995:66). Hierdie opdrag is deel van die middelaarsrol van die priesters ten opsigte van God se verhouding met sy volk (Rooker, 2000:153).

Blessing in the Pentateuch and more particularly in the Book of Numbers includes numerous descendants, fruitful land, good

1 Die betekenis van die seën in Numeri 6 word onder punt 5.1 hanteer. 
health, long life, protection from enemies, and God's presence.

(Cole, 2000:129.)

In dié seën word die Naam van Jahwe op die volk gelê, dit wil sê die priesters bring die Naam van die Here oor die volk tot stand. In die Hebreeus word dieselfde woord vir "tot stand bring" ("op die volk lê") gebruik as in Numeri 6:26: En Hy sal vrede "gee": "tot stand bring". Terwyl God self sy Naam tot stand bring/vestig (Deut. 12:5; 1 Kon. 9:3), het Hy die opdrag daartoe hier in die hande van die priesters gelê. Die "gevestig wees" van die Naam word in die liturgie geaktualiseer (Van de Kamp, 1998:319).

\subsection{Voorlopige afleidings uit Ou-Testamentiese gegewens}

- God alleen is die bron van alle seëning en Hy seën van die begin af sy volk sodat hulle hulle roeping kan vervul.

- Seën is meer as 'n bede of 'n wens; dit is God se effektiewe krag wat die seënspreuke prakties 'n werklikheid laat word.

- Die persone wat in die amp van priester staan, kry die volmag om in die Naam van die Here die seën, in woorde wat regstreeks van God kom, af te kondig.

\section{Lukas $24: 50-53$ as wentelpunt}

\subsection{Lukas beklemtoon die gedagte van seën}

Lukas 24 kan in die openbaringsgeskiedenis van die seën as 'n soort wentelpunt gesien word. Dit gaan veral oor die feit dat Jesus spesifiek na sy dood en opstanding en tydens sy hemelvaart die dissipels seën, as verteenwoordigers van die nuwe volk van God. Wat kan uit hierdie gebeure oor die betekenis en effek van die seën afgelei word?

Vooraf moet dit gestel word dat die evangelie volgens Lukas meermale die gedagte van seën beklemtoon: verskillende vorme van eul og ew word in Lukas 1:42, 68-69; 2:28-32 aangetref. Louw en Nida (1988:442) definieer eul ogew soos volg: "The implification is that the verbal act (of bestowing divine favor on) itself constitutes a significant benefit." In die LXX is eul ogia/eul oget o" die vertaling van die Hebreeuse ברכ en dit word toegepas op God; in die Nuwe Testament verwys dit na God as die Vader van Jesus Christus. "Thus although derived from the LXX the terms for blessing are now infused with new meaning." (Morton, 2006:544.) 


\subsection{Die ewige Hoëpriester seën sy nuwe volk}

Heel aan die begin van die fyn beplande evangelie verhaal Lukas die geskiedenis van Sagaria, 'n priester wat die vermoë verloor het om die volk te seën nadat hy namens die volk geoffer het. Weens sy ongeloof aan die belofte van God kon hy nie sy priesterlike plig voltooi en die seën in die Naam van God afkondig nie. Die priesterlike seën is altyd ná die offer uitgespreek om so ook aan te dui dat God die offer aanvaar en dit met sy seën beantwoord. Aan die einde van die Evangelie toon Lukas aan dat Jesus Christus die volmaakte offer gebring het, dat God die offer aanvaar het en dat die seën by sy hemelvaart juis dit bevestig. Die wyse waarop Lukas sy evangelie eindig, sluit aan by dit wat in Levitikus 9:22-23 beskryf word: net soos die hoëpriester, wanneer hy op die groot feesdae uit die tempel gekom het, hef Jesus sy hande op en seën as ewige Hoëpriester die dissipels (Kapic, 2005:251). Die taal wat Lukas in die beskrywing van hierdie geskiedenis gebruik vir die "opheffing van die hande" vir die priesterlike seën is die terminus technicus. Dit word bevestig deur die byvoeging "en hulle geseën". "He showed that the office of blessing, which was enjoined on the priests under the Law belong truly and properly to Himself." (Calvin, 1965:392.)

Waar Aäron sy arms kon ophef en as gevolmagtigde afgekondig het dat God se aangesig oor die volk skyn, kon die dissipels letterlik die aangesig van God se genade in Jesus sien terwyl Hy opgevaar het na die hemel: hulle kon Hom sien wat self Genade is. God se sigbare goedheid wat in die seën aan hulle toegesê is, word in Jesus geaktualiseer. Die vrede wat hulle in die seën kon toeëien, ken hulle nou as die Here wat met sy opstanding die ware Vrede vir hulle geword het. "The great High Priest came and not only pronounced the benediction, but he became the benediction." (Kapic, 2005:252.) Daarom is Lukas 24:50-53 'n wentelpunt in die openbaring van die seën.

Dit zegenen was niet maar alleen een uitspreken van heilwensen, zoals wij alleen maar beden van zegen uiten kunnen, doch een metterdaad schenken van datgene, wat de Heere hun wilde doen toekomen; heil, vrede, kracht, Zijn hulp, blijdschap in Hem, vertrouwen, moed, en alles wat zij voor zich in hun arbeid nodig hadden en zouden hebben. 's Heeren woord is steeds een woord met macht, ook Zijn zegenwoord. (Greijdanus, 1955: 300.)

In sy weggaan van hulle kom Jesus weer nuut in sy Heilige Gees terug om nooit meer van sy gemeente weg te gaan nie. So seën Hy hulle en stuur sy Gees op hulle sodat hulle met al die hemelse 
seëninge geseën kan word (Ef. 1:3). Calvyn koppel ook in sy verklaring van Lukas 24:50-53 Christus se priesterlike seën aan die stuur van sy Gees (Calvin, 1958:246).

Daar is 'n noue verwantskap tussen Lukas 24, Handelinge 1 en Matteus 28. Op al drie plekke word aspekte van Jesus se afskeid en die hemelvaart geskets (Nolland, 1993:1225). Die seën lei tot die uitgaan en "dissipels maak" en "getuies wees" in Jerusalem, Judea, Samaria tot die uiterstes van die aarde. In Lukas 24 verseker Christus sy nuwe volk, deurdat Hy hulle seën, dat sy offer volmaak was, deur God aanvaar is en dat hulle 'n nuwe hart en lewe gekry het en mag voortgaan om onder sy seën sy getuies te wees. Jesus

Christus gee aan die kerk 'n dieper en ryker verstaan en belewing van die betekenis van die seën.

\subsection{Voorlopige afleidings uit Lukas 24:50-53}

- Lukas beskryf meer geleenthede waar van die seën sprake is en daarom is die seën van sy dissipels by sy hemelvaart ' $n$ soort klimaks van sy boodskap.

- Jesus sluit by die Ou-Testamentiese priesters se seënhandeling aan, maar gee daaraan 'n nuwe wending deurdat Hyself die Seën is en dit so aktualiseer.

- Die koppeling van Jesus se seën by sy hemelvaart aan die uitstorting van die Heilige Gees het ook 'n wegstuurdimensie: onder die seënende hand van die Here Jesus moet die dissipels die evangelie gaan verkondig.

\section{Grondslae vir die plek en funksie van die seëngroet in die erediens}

Die seëngroet wat meestal in die samekoms van die gemeente gebruik word, kom uit die seëngroet in die Pauliniese briewe en uit die eerste hoofstuk van die boek Openbaring.

\subsection{Die Pauliniese briewe}

Dit is opmerklik dat die groet altyd volg op die aanduiding van Paulus se gesag in sy briewe. Hy stel homself as apostel van die Here Jesus bekend en bring dus gesaghebbend die seëngroet van God en Christus oor (Vos \& Pieterse, 1997:211). Janse van Rensburg (1999:1567) stel dit so: 
Paulus gee vir hulle iets met sy groet: die genade en vrede van God en die Here Jesus! Dis nie 'n hoop wat hy uitspreek, of selfs 'n gebed waarin hy God vra om dit aan hulle te gee nie. Hy maak dit hulle s'n, hy sê dit toe aan hulle.

Wat moet die werkwoord in die groetseën wees wat by umin ingedink behoort te word? E ih (optatief) is op grond van 1 Petrus 1:2 en 2 Petrus 1:2 sowel as Judas 2 die mees voor die hand liggende. In sy kommentaar op 1 Timotheus skryf Ridderbos (1967:43):

Als apostolische groet is zij ook niet slechts een zegen-wens, maar een toezegging van Godswege. In een zegengroet wordt aan de geadresseerde het heil des Heren in ongedifferentiëerde zin toegezegd.

Die groet in die briewe in die Grieks-Romeinse wêreld gedurende die tyd van Paulus het met die woord cairein (groete) geëindig. Paulus het hierdie vorm gebruik, maar met slim woordspeling die verwagte cairein doelbewus met cari" (genade) vervang. Hy gebruik hierdie term byna 100 keer in sy briewe en beklemtoon elke keer die geweldige idee van die vrye, spontane, onverdiende guns van God. Paulus het egter die standaard Grieks-Romeinse formule nog verder verander. Paulus vervang nie net cairein met cari" nie, maar voeg telkens die woord eirhnh (vrede) daarby (Rom. 1:7; 1 Kor. 1:3; 2 Kor. 1:2; Gal. 1:3; Ef. 1:2; Filip. 1:2; Kol. 1:2; 1 Tes. 1:1; 2 Tes. 1:2; Fil. 3; Hawthorne, 1983:11). So word 'n gewone groet verhoog tot 'n seëngroet, want Paulus dui daardeur aan dat dit God is wat hulle groet en dat Hy dit doen deur genade en vrede in hulle harte in te stort. Die apostel beklemtoon die eenheid tussen Christus en God die Vader as die gemeenskaplike bron van genade en vrede (Hawthorne, 1983:12).

Paulus gebruik in sy brief aan die Romeine die seëngroet: genade en vrede.

Het eerste duidt de bron aan van de tweede: 'genade' is dat gene wat God in Christus heeft gewrocht en geschonken: 'vrede' is de daaraan beantwoordende heilstoestand in de meest omvattende zin van het woord.

Ridderbos (1959:28) stel dit soos volg: die gemeente wat deur God en Christus gegroet word, is daarom 'n geseënde gemeente na wie God met genade en vrede kom. Die seëngroet en gebaar van die seënende hande is nie bloot seremoniële gebruike in die Nuwe Testament nie, maar eskatologiese uitdrukkings van die werking van God se Gees (Morton, 2006:544). 


\subsection{Openbaring 1:4-5}

Die seëngroet in Openbaring 1:4-6 is geplaas in die tradisionele vorm van die profetiese proloog en kom ooreen met die seëngroet in die Pauliniese briewe (Fiorenza, 2001:6). Die weglating van eih maak die seëngroet des te kragtiger, meer as bloot ' $n$ bede of ' $n$ wens. "Zijn inhoud wordt metterdaad geboden of verleend, ofschoon hij slechts in het geloof ontvangen kan worden, Luc. 10:5, 6; Joh. 14:27; 20:21." (Greijdanus, 1925:13.) C a ri" dui onverdiende, selfs verbeurde guns aan. Eirhnh is die deur Christus herstelde harmonie tussen God en die mens in sy volle omvang. Die woord vrede vertaal die Hebreeuse gedagte van shalom, 'n gemeenskap wat saamleef in harmonie, vreugde, liefde en vrede (Walhout, 2000:19).

A p o dui die bron aan waaruit hierdie genade en vrede voortvloei. Johannes volg in Openbaring 1:4-5 Paulus se styl en beklemtoon ook die Bron van genade en vrede. Hy laat die verwysing na God as "Vader" weg uit die seëngroet. "In fact, he transforms this part of the traditional Christian salutation by refering to God using the very elaborate set of three clauses, each of which functions as a divine title." (Aune, 1997:30.) Die frase "van Hom wat is en wat was en wat kom" sinspeel op die weergawe van die Septuagint van Eksodus 3:14, waar die naam "Ek is wie Ek is" voorkom. Van God word eerste "Wie is" genoem, want Hy ken geen ontstaan of begin en by Hom is daar geen ontwikkeling of verandering nie. Hy is altyd dieselfde. Daarom was Hy vroeër steeds wie Hy nou is en sal Hy so bly. Met die woorde "wat kom" word die eskatologiese koms beklemtoon. Hy is eintlik komende, omdat Hy as't ware van ewigheid op weg is totdat Hy eenmaal in volle heerlikheid sal verskyn en sy Godheid deur niks versluier sal wees nie. "God awaits the believer in future. He is behind, among, and ahead of the church." (Witherington, 2003:75.) God is in volle beheer van wat ook al in die hede gebeur en Hy bepaal wat "sal kom" net soos Hy bepaal het wat in die verlede gebeur het (Walhout, 2000:19). Met die Naam waarmee God voorgestel word, word aangedui wie Hy in Homself is en hoe Hy met betrekking tot die wêreld staan. Dit geld ook die benoemings waarmee Jesus beskryf word. Dit verklaar ook waarom die Heilige Gees met "die sewe Geeste" benoem word, want dit raak sy verhouding met die sewe gemeentes.

Die preposisie apo word herhaal om die selfstandigheid van die Heilige Gees aan te dui, dit wil sê dat Hy soos die Vader en die Seun hierdie genade en vrede skenk en werk. Hy is in wese aan die Vader en die Seun volkome gelyk. Die feit dat die sewe Geeste hier tussen die Vader en die Seun genoem word, sluit die gedagte aan 
onpersoonlike geeste en engele uit. Johannes beweeg met hierdie seëngroet vanuit die heilige der heilige na waar God troon en vanwaar die bron van heil ontspring, na waar die Heilige Gees die sewe lampe van die kandelaar van die gemeentes laat brand, en dan weer na die voorhof waarin die diens van die versoening deur die Here Jesus vervul word. Dit is dus waarom hierdie volgorde in die seëngroet gevolg word, die Heilige Gees tweede genoem word en waarom vervolgens breedvoerig die verlossingswerk van die Here Jesus in die lig gestel word.

In die beskrywing van Jesus Christus word nie van genitiewe, maar wel van nominatiewe benoemings gebruik gemaak. Daarmee word die Here Jesus geopenbaar na sy volle grootte. Die drie titels in vers 5 korrespondeer met drie belangrike aspekte van werksaamhede. Hy word genoem die Betroubare Getuie, die Eersgeborene wat uit die dood opgestaan het en die Heerser oor die konings van die aarde. Hy is in sy wese die betroubare getuie en daarom die getroue kommunikeerder van die goddelike verlossingsboodskap. Die noue verband tussen hierdie betroubare getuienis en sy opstanding impliseer dat die getuienis die dood en opstanding as kernelemente bevat (Witherington, 2003:76).

$\mathrm{Hy}$ is die eersgeborene uit die dood en daarmee word gesê dat Hy die voorloper en maghebber is. Hier val die nadruk op die feit dat Hy heerskappy voer oor die dood deur sy opstanding uit die dood. Hy het weer lewend geword, en is die eerste wat nie weer sal sterwe nie. Hy het die mag van die dood sodanig gebreek dat ook ander deur Hom sal kan opstaan uit die dood. Die dood word hier genoem as die mag waaroor dit die onmoontlikste is om gesag uit te oefen.

As firstborn from the dead, the theologia gloriae, 'theology of glory, referring to the resurrection triumph of Christ', is deftly combined with the theologia crucis, 'theology of the cross', for the term 'firstborn' has royal/messianic associations, while the phrase 'of those who are dead' refers to Jesus' triumph over death. (Walhout, 2000:20.)

As heerser oor die konings van die aarde word sy toekomstige rol as universele soewereine heerser beklemtoon (Aune, 1997:41). Jesus is nou, en was dit sedert sy opstanding en hemelvaart, die beheersende mag oor alles wat op aarde gebeur. Sy mag is nie weggesteek nie, maar is funksioneel en sigbaar oral waar die evangelie geglo word, oral waar die Gees van Christus gelowiges beheers en ooral waar die kerk groei. "The power of Christ from heaven is the most decisive influence within the ongoing civilization of earth." 
(Walhout, 2000:20.) Die maghebbers is hier verteenwoordigend van die belangrikste aardse magte en dit beteken dat alle aardse magte onder Hom gestel is, selfs die geringstes. Ook die konings van die aarde staan onder sy mag, moet Hom dien, aan Hom gehoorsaam wees en onder Hom buk.

\subsection{Voorlopige afleidings oor die grondslae van die seëngroet in die erediens}

- Met die toesegging van die seëngroet bewerk die Bron daarvan genade en vrede. In die uitspreek daarvan deur die gevolmagtigde stort God genade en vrede in die gemeente.

- Genade dui op onverdiende, selfs verbeurde, guns van God en vrede skep 'n gemeenskap wat in harmonie, liefde en blydskap saamleef.

- Die benoemings waarmee God, die Heilige Gees en Jesus Christus beskryf word, dui aan wie die Drie-enige God is en hoe Hy met betrekking tot die wêreld staan en optree.

\section{Grondslae vir die plek en funksie van die wegstuurseën in die erediens}

Die wegstuurseën wat meestal in die samekoms van die gemeente gebruik word, kom uit Numeri 6:24-26 en uit 2 Korintiërs 13:13. Wat kan uit hierdie twee gedeeltes afgelei word oor die betekenis en funksie van die wegstuurseën?

\subsection{Numeri 6:22-27 as wegstuurseën}

\subsubsection{Die struktuur van Numeri 6}

Die seën van Numeri 6 bestaan uit slegs drie reëls en in die Hebreeus word vir dié drie reëls drie, vyf en sewe woorde respektiewelik gebruik (Davies, 1995:67). Die eerste reël bestaan uit 15, die tweede uit 20 en die derde uit 25 konsonanttekens (Korpel, 1989:5-7).

As the lines of the blessing lengthen, their content becomes richer, producing a crecendo that culminates in the word Peace. The first clause of each line evokes God's movement towards his people, the second clause his activity on their behalf. (Cole, 2000:129.)

Die wonderlike struktuur van die seën van Numeri 6 dien daartoe dat die seën so diep moontlik in die harte van die geseëndes kan 
indaal, sodat die seën daar kan ontplooi en in hulle alledaagse lewe 'n effek kan hê. Grammaties is dit nie nodig om die Naam van Jahwe drie keer te herhaal nie, maar hierdie besondere struktuur, saam met die finale woord wat van God kom ("en Ek sal hulle seën") dien daartoe om uiters sterk te beklemtoon dat die God van Israel die bron is van alle genade, seëninge, hoop en vrede (Cole, 2000: 129).

\subsubsection{Opmerkings oor die inhoud van Numeri 6}

Die Here gee aan Moses 'n opdrag en daarom word die infinitief "sê!" hier gebruik as 'n imperatief (Levine, 1993:227). Die priester moet daarom elke keer die presiese woorde gebruik wat God deur Moses aan hulle voorskryf (Ashley, 1993:128). In die eerste deel van die drievoudige seën ("Die Here sal julle seën en julle beskerm") word met seën bedoel dat die Here die volk met krag toerus. Aäron en die priesters moet dus die volk met die krag wat van die Here kom, begiftig. "Yahweh would provide them with wealth and possessions (cf. Gen. 24:35), land and progeny (Gen. 35:9 ff.) fertility, health and success in battle (cf. Deut. 7:12 ff.; 28:1 ff.)." (Davies, 1995:68.) Die begrip seën het in die mond van een Israeliet teenoor die ander die betekenis van "afbid van voorspoed". In die sin van Numeri 6 beteken seën egter die afkondig of deurgee van God se seën (Calvin, 1958:246).

In die tweede deel ("Die Here sal sy aangesig oor julle laat skyn") word 'n metafoor gebruik om God se goedgesindheid en guns tot uitdrukking te bring. Wanneer iemand sy gesig sigbaar maak in die rigting van 'n ander, beteken dit dat hy hierdie gesig (aangesig) helder voor hom laat skyn, hom vriendelik aankyk (Spr. 16:15).

When ones face 'lights up' he is well disposed, which is the antithesis of a fierce countenance, which conveys an unkind disposition. When God is well disposed, his face brings blessings and power. (Levine, 1993:228.)

Genade beteken dat daar by die ontvanger skuld en by die gewer liefde en ontferming is. Uit die getuienis van die Ou en Nuwe Testament staan dit vas dat genade 'n fundamentele aspek van Jahwe se karakter is. Hy kan dit dus vryelik aan mense skenk, wat dit uit die aard van hulle karakter nie self kan voortbring en ook geensins verdien nie (Ashley, 1993:130).

In die derde en finale deel van die seën uit Numeri 6 ("Die Here sal sy aangesig oor julle verhef") gaan dit oor die liefhê van die persoon. God gee Homself in liefde met al die rykdom van sy wese aan die 
volk. Die Here se "verhef van sy aangesig" is 'n uitdrukking wat vreugde en minsaamheid aandui, amper in funksie gelykstaande aan 'n vriendelike "glimlag". "The majestic smile of God upon the community of faith and each constituence individual will bring abiding and ultimate peace." (Cole, 2000:131.) Die Hebreeuse woord shalom het 'n baie ryker betekenis as die Afrikaanse woord vrede, want dit sluit materiële voordele in soos voorspoed, maar ook innerlike belewing van harmonie, heel-wees en goeie welstand (Davies, 1995:69). "In essence shalom means fullness of life and wholeness in all areas of life: material, familial, societal and religious." (Ashley, 1993:131.) Vrede dui op harmonie, en daarom ook geluk en vrye lewensontplooiing en lewensblydskap.

Nadat die seën woordeliks voorgeskryf is, dui God deur Moses aan dat die priesters voortaan op hierdie wyse God se Naam op die volk moet lê. Deur hierdie daad verbind God Hom ten nouste met die volk. Hy leef in 'n liefdesverhouding met hulle (Gispen, 1950:120). Die wyse waarop God dus sy Naam op die volk lê, is deur die uitspreek van hierdie omvattende, ryk en onverdiende seën (Ashley, 1993:128). Dit is die rede vir die duidelike versekering van God: wanneer sy Naam met hierdie woorde op die volk gelê word, seën Hy hulle self. Die seën wat God in Numeri 6:24-26 aan die priesters voorskryf, word omring deur 'n raamwerk wat die goddelike outeur en die menslike gevolmagtigdes identifiseer (v. 22), wat die priesterlike plig om die seën aan die volk af te kondig, voorskryf (v. 23) en wat die uitkoms van die seën beskryf (v. 27).

God deposits His name with the priests, that they may daily bring it forward as a pledge of His good will, and of the salvation which proceeds from thence. Whatsoever the ministers of the Church do by God's command, is ratified by Him with a real and solid result; since He declares nothing by His ministers which He will not Himself fulfil and perform by the efficacy of His Spirit. But we must observe that He does not so transfer the office of blessing to His priests, as to resign His right to them; for after having entrusted this ministry to them, He claims the accomplishment of the thing for Himself alone. (Calvin, 1958:247.)

In die liturgiese tradisie van Israel het die seën gedien om die aanbidders seënend in die wêreld terug te stuur (Ashley, 1993:127). Jahwe se seën op sy gelowige volk moes verder 'n instrument wees: vanaf sy volk moes God se seëninge op die nasies van die wêreld kan kom (Gen. 12:3, 22:18; vgl. Ps. 67:1-2; Cole, 2000:130). 


\subsection{Korintiërs 13:13}

Hierdie brief bevat die mees uitvoerige seëntoesegging van al die Nuwe-Testamentiese briewe en daarom word hierdie seën ook algemeen in die liturgie van die Christelike kerke gebruik. Hierdie toesegging van seën volg op die oortuigende wyse waarop Paulus vir 'n laaste keer sy apostoliese gesag aandui (v. 10). Dit is dus duidelik dat Paulus die seën met dieselfde gesag uitspreek. Soos in al die ander briewe in die Pauliniese korpus eindig hierdie brief met ' $n$ seëntoesegging wat begin met cari" (Thrall, 2004:914). Die vraag moet ook gevra word of die formule wat Paulus hier gebruik 'n seëntoesegging of 'n wens is. Bid hy dat die goddelike genade, liefde en gemeenskap met die gemeente mag wees, of verklaar hy gesaghebbend dat hierdie gawes hulle s'n is? Ook hier ontbreek die werkwoord en een of ander vorm van eimi moet hier veronderstel word, maar watter een? Moet dit ei h (optatief) wees, of eerder es t w (imperatief)? Wanneer die Pauliniese seën hier met die seën in Romeine 15:5, 13 en 1 Tessalonisense 3:11, 12-13; 5:23 vergelyk word, moet die optatief-opsie gekies word (Thrall, 2004:916).

McCant (1999:170) stel "The benediction at v. 13 is the most theologically elegant in Pauline letters." Paulus beklemtoon hierin genade, liefde en gemeenskap. Genade het sy oorsprong in Christus, liefde begin met God en gemeenskap vloei van die Heilige Gees. Die volgorde is dat die "genade van die Here Jesus Christus" eerste staan, want dit is deur Hom wat mens geword het, gekruisig is en oorwin het, dat gelowiges die Vader se liefde leer ken het (Joh. 1:14-18; Rom. 5:8-11; Hebr. 9:14) en dat hulle hul kan verheug in die gemeenskap van die Heilige Gees. Die begrip genade bring die totale seën van die verlossing tot uitdrukking (Garland, 1999:555). "Die liefde van God" is die duidelikste sigbaar in die offerdood van Christus. "Die gemeenskap van die Heilige Gees" word soms as 'n objektiewe genitief gesien, maar dit kan ook verstaan word as 'n subjektiewe genitief. "Posing this as an either/or question may fail to do justice to the richness of Paul's thought. It may best be understood as a 'plenary' genetive which incorporate both ideas." (Garland, 1999:556.) "The Holy Spirit's work is to create a true "fellowship of believers', which in turn is a sign of the new age." (2 Kor. 1:22; 5:5; Martin, 1986:506.) Paulus verklaar dat die Korintiërs gemeenskap met die Gees het, soos wat hulle die genade van Christus en die liefde van God ervaar. In elke geval het hy die verhouding met die drie Persone van die goddelike Drie-eenheid in gedagte (Thrall, 2004:919). Die gelowiges staan nie los van mekaar nie, maar word deur die inwonende Heilige Gees aan God en aan mekaar verbonde gehou. 


\subsection{Voorlopige afleidings oor die grondslae van die wegstuurseën in die erediens}

- Die struktuur van die seën in Numeri 6 en 2 Korintiërs 13:13 dien daartoe dat die seën so kragtig moontlik in die harte van die geseëndes indring, sodat die seën daar kan ontplooi en in hulle alledaagse lewe effek kan hê.

- Die seën word deur gevolmagtigdes (priesters in die Ou Testament en apostels in die Nuwe Testament) op die volk gelê, omdat dit God self is wat sy seën in hulle instort.

- In die liturgiese tradisie van Israel het die seën gedien om die aanbidders seënend in die wêreld terug te stuur en om as 'n instrument te dien sodat God se seëninge deur middel van sy volk op die nasies van die wêreld kan kom.

- Met "beskerming", "genade", "vrede", "liefde" en "gemeenskap" word die volle rykdom van God se gawes aan die volk toegesê.

\section{Perspektiewe uit die kerkgeskiedenis vir die seën}

Weens die beperkte omvang van hierdie artikel word nie gepoog om 'n volledige oorsig oor die geskiedenis vanuit die oorspronklike bronne te gee nie. 'n Kort oorsig oor wat in die geskiedenis van die seën gebeur het, kan meehelp om spesifieke liturgiese riglyne oor die betekenis en funksie van die seën aan te dui.

In die Vroeë Kerk is die kategumene en andere deur die biskop geseën wanneer hulle aan die einde van die eerste deel die diens moes verlaat. Die gemeente is ook later in die diens geseën. In die Middeleeue verval die seën en word dit deur die mis vervang wat met sy sluitingswoorde die samekoms beëindig sonder dat 'n seën op die gemeente gelê word. Dit is merkwaardig dat eers sedert die Reformasie die priesterlike seën weer deel word van die erediens. Die Reformatore voer die seën weer in en kombineer dit met die wegstuurformule. Luther bring in 1523 die Trinitariese en Aäronitiese seën as wegstuurseën terug en so ontstaan 'n handeling in die vroeg-Reformasietyd wat diep in die Protestantse kringe sou wortel. Zwingli neem dit oor en Bucer en Calvyn gebruik die seën van Numeri 6 om die gemeente seënend weg te stuur (GKSA, 1985: 402). Die Sinode van Dordrecht (1574) skryf die wegstuurseën aan die kerke voor.

In die geskiedenis van die liturgie het die seën verskillende betekenisse en funksies gehad. Die seën word in die Roomse mis as 'n 
wens verstaan en in die Oosterse liturgieë is dit gesien as 'n gebed om die seën van die Here. In Reformatoriese kringe is dit beskou as 'n toesegging van God deur die mond van die geordende herder en leraar (Barnard, 1985:577). Die juisste siening, volgens die Reformatore, is dat dit 'n verkondiging, afkondiging van die Here se seën is wat met die gesag van die Oorsprong van die seën kom. Die seën is 'n gawe, 'n donation, van die Here wat in sy Naam aan die gemeente verkondig en toegesê word. Die Bron van die seën is die Drie-enige God en Hy is die eintlike verlener van sy seën. Wat Hy spreek, geskied en wat Hy gee, is onmiddellik werksaam as dit in die geloof toegeëien word (Brienen, 1987:222). Die seën word gelê op die gemeente en die volle werk van God Drie-enig is daarin saamgevat. Die seën werk nie magies nie, maar bly gesaghebbende spreke wat gelowig ontvang moet word (Barnard, 1985:577).

\section{Praktykteoretiese perspektiewe en voortvloeiende liturgiese riglyne vir die seën}

Uit die voorlopige afleidings uit die Skrif en die geskiedenis kan die volgende praktykteoretiese perspektiewe en liturgiese riglyne afgelei word:

\subsection{Die seën is onontbeerlik vir die lewe van die gemeente}

Samevattend kan die seën beskryf word as die effektiewe krag van God wat Hy deur sy Woord uitoefen. Met die seën laat Hy sy beskerming, genade, vrede, liefde en gemeenskap, die volle rykdom van sy gawes, 'n werklikheid in die gemeente se lewe word. Die seën is dus méér as 'n blote wens (Rooms Katolieke), méér as 'n bede (Oosterse kerk); dit is 'n toesegging van God deur die mond van sy geordende dienaar (Reformasie). Die verskil is dus soortgelyk aan die verskil tussen Skriflesing en gebed in die erediens.

Die twee begrippe wat in elke seëntoesegging gebruik word, is genade en vrede. Genade dui op onverdiende, selfs verbeurde, guns van God en vrede skep 'n gemeenskap wat in harmonie, liefde en blydskap saamleef. Die kragtige benamings van die Bron in al die seëntoeseggings (Num. 6; Openb. 1; 2 Kor. 13:13 en in die ander Pauliniese briewe) toon aan dat alleen God hierdie gawes aan die gemeente kan gee. 
- Die praktykteoretiese perspektief wat hieruit afgelei kan word, is die volgende:

Die gemeente van Jesus Christus moet in hulle samekoms die seën van die Here as 'n onontbeerlike gawe ontvang. Sonder hierdie seën is gemeenskap met God en mekaar, geloofsvertroue en nakoming van elkeen se roeping in die wêreld nie moontlik nie.

\section{- Die liturgiese riglyn:}

Die gemeente moet opgevoed en toegerus word om die betekenis, funksie en noodsaak van die seën te verstaan, om elke keer die seën bewustelik in die geloof toe te eien om daarmee te gaan lewe en te werk.

\subsection{Die seëngroet is noodsaaklik vir die verdere handelinge in die erediens}

Hoekom seën God sy volk twee keer in die samekoms van die gemeente? Die benaming seëngroet dui aan wat in werklikheid gebeur. Die volk van God vergader nadat hulle individueel 'n week onder sy seënende hand geleef, gewerk en ernstig geworstel het met hulle smet, sonde, versoekings en beproewings. Wanneer hulle dan saamkom, is dit nie 'n sosiale byeenkoms nie, maar dra die samekoms die karakter van 'n ontmoeting van God met sy volk, sy volk met Hom en met mekaar. God maak 'n seënende intrede en die klem val op die seën waarmee Hy sy volk as vergaderde liggaam van Christus groet.

Die seëngroet se seëninge is toegespits op elke handeling van die erediens en juis deurdat die gemeente die seëngroet gelowig toeeien is hulle in staat om aktief en tot eer van God aan die handelinge deel te neem. Die seëngroet is onontbeerlik vir die gemeenskap met God en met mekaar. Die formule wat in die samekomste van die gemeente vir die groetseën gebruik moet word, moet woorde van God wees, gerig aan gemeentes (GKSA, 1997:744). Die gebaar by die seëngroet moet een wees van toesegging en nie van gebed nie (Handelinge, 1985:412).

\section{- Praktykteoretiese perspektief:}

Die seëngroet stort al die gawes in die gemeente wat lidmate in staat stel om vrugbaar aan die erediens te kan deelneem. 


\section{- Liturgiese riglyn:}

Die gemeente moet toegerus word om weer die diepsinnige betekenis en funksie van die seëngroet te herontdek. Dit is noodsaaklik vir die gemeente dat die seëngroet toegesê en nie bloot afgebid word nie.

\subsection{Die wegstuurseën stuur gelowiges as geseëndes na hulle leefwêreld om hulle roeping te kan vervul}

Die erediens moes in die Ou en Nuwe Testament die deelnemers altyd weer lei na die konkrete lewe van elke dag. Die erediens geskied in 'n lewende wisselwerking met die alledaagse lewe, wat in die erediens sy dinamiese motivering vind. Die wegstuurseën van die erediens versterk die erediensdeelnemer innerlik én uiterlik en stel hom in staat om die seën met ander te deel (Vos \& Pieterse, 1997:257). Seën en sending, sending en seën hang ten nouste saam. Dit gaan dus om die ontvang én die verdere deurgee van die verlossende, herstellende en bewarende krag van God wat aan die wêreld versoening en vrede gee (Barnard, 1985:578). Die aanbidding waarop die samekoms van die gemeente uitloop, gaan voort in die daaglikse lewe van elke lidmaat en daarom word hulle geseën.

Die seën van die Here beteken die wegstuur van die gemeente om onder die seënende hand van die Here tot die aksie van diens oor te gaan. Dit moet liturgies in woord en gebaar duidelik wees dat die dienaar gemagtig is om die seën van die Verbondsgod, namens Hom, op die Verbondsgemeente te lê (Handelinge, 1997:766).

\section{- Praktykteoretiese perspektief:}

Die gemeente is begenadig om deur God self teruggestuur te word in hulle leefwêreld deurdat Hy sy seën in hulle stort. Sonder die wegstuurseën kan die gemeente nie hulle roeping vervul nie - 'n roeping veral om getuies van Christus te wees.

\section{- Liturgiese riglyn:}

Die gemeente moet toegerus word om nie net die betekenis en funksie van die wegstuurseën te verstaan nie, maar ook om uit te gaan en die erediens van die lewe as getuies van Christus daagliks voort te sit. 


\subsection{Die gevolmagtigde bedienaar en die toesegging van die seën}

In die Ou Testament het slegs die persone wat in die amp van priester staan die volmag gekry om in die Naam van die Here die seën, in die woorde wat regstreeks van God gegee is, af te kondig. Die seën word ook in die Nuwe Testament deur gevolmagtigdes (apostels) aan die volk toegesê. Daarmee word beklemtoon dat die seën regstreeks van God kom. In die briewe van die apostels maak hulle 'n duidelike verskil tussen gebede en seëntoeseggings. Onder die reformatore van die sestiende eeu is die seën gesien as 'n toesegging van God deur die mond van die geordende herder en leraar.

Die een wat die seën uitspreek is 'n bemiddelaar: hy kondig iets aan, gee iets deur, sonder om daaroor self vrymagtig die beskikking te hê. Die geroepe voorganger lei, as dienaar van God, kragtens die apostolaat in die dienste in elke gemeente (vgl. onder andere Hand. 3:11; 5:19, 20, 40-42; 6:2, 8; 9:15; 13:1, 2; 14:22, 23; 15:22; 1 Kor. 16:13-20, ensovoorts), en voer die besondere handelinge uit kragtens 'n goddelike roeping en missie. Dit behels onder andere die seëngroet en die wegstuurseën en die bediening van die sakramente (GKSA, 1997:732). Die vraag is of die gemeente die seëngroet en wegstuurseën as toesegging moet ontbeer as daar wel 'n geroepe en gevolmagtigde bedienaar deelneem aan die erediens, maar nie die prediking en ander liturgiese handelinge behartig nie? Die antwoord hierop moet 'n besliste "nee" wees. Uit die erfenis van die reformasie is dit duidelik dat een persoon nie al die handelinge in die erediens hoef te behartig nie. Daar is ' $n$ beduidende verskil in die effek op die lewe van die gemeente wanneer die seën afgebid word en wanneer die seën toegesê word. Al word by die afbid van die seën geglo dat die gebed verhoor sal word, het dit nie die gesag wat die afkondiging van die seën deur 'n gevolmagtigde bedienaar van die Woord het nie.

\section{- Praktykteoretiese perspektief:}

Die gevolmagtigde bedienaar lê die seën wat regstreeks van God kom gesaghebbend op die gemeente.

\section{- Liturgiese riglyn:}

Waar 'n gevolmagtigde bedienaar van die Woord in die samekoms van die gemeente teenwoordig is, behoort hy die seën wat regstreeks van God kom, af te kondig. 


\subsection{Die gemeente moet die seën beaam en gelowig aanneem}

Een van die duidelikste reformatoriese liturgiese handelinge is dat die amen in die sestiende-eeuse Reformasie aan die gemeente teruggegee is. Dit was die gebruik dat die "amen" in die Vroeë Kerk en in die eerste eeue deur die gemeente uitgespreek is (Brienen, 1987:186). Met "amen" word die seën wat God aan die gemeente skenk gelowig toegeëien. Soms is die liturg, byvoorbeeld in die voorgaan in gebede, die mond van die gemeente wat namens die gemeente die "amen" uitspreek, maar dit is steeds die gemeente se handeling.

By die seëngroet ontvang die gemeente God se gawes vir die ontmoeting met God en mekaar deur die seën met "amen" toe te eien. In die wegstuurseën in die samekoms gaan die volk van God onder sy seënende hand ' $n$ nuwe tydperk van genade binne. Die gemeente moet die wegstuur beaam en die seën aktief aanneem en toeëien deur die "amen" uit te spreek (Vos \& Pieterse, 1997:256). Dit kan ook gebeur deur die amen te sing.

\section{- Praktykteoretiese perspektief:}

Dit is noodsaaklik dat die gemeente die seën gelowig moet toeëien deur 'n aktiewe handeling, naamlik deur daarop "amen" te sê.

\section{- Liturgiese riglyn:}

Die gemeente moet bewus gemaak word dat die handeling van toeëiening van die seën plaasvind wanneer hulle daarop "amen" sê. Hierdie handeling moet verkieslik 'n hoorbare aksie van die gemeente as eenheid wees, deur "amen" uit te spreek of te sing.

\section{Slot}

Die handeling van die seën in die erediens is ' $n$ handeling van die Drie-enige God wat deur die dienaar die seën op die gemeente lê en dit in die harte van die erediensdeelnemers instort. Die gemeente kan dus lewe onder die troos en dryfkrag van die inhoud van die seën wat hulle gesaghebbend ontvang het. Op hierdie wyse kan hulle in die daaglikse lewe vir mekaar en ander tot 'n seën wees. 


\section{Geraadpleegde bronne}

ASHLEY, T.R. 1993. The book of Numbers: the new international commentary on the Old Testament. Grand Rapids: Eerdmans.

AUNE, D.E. 1997. Revelation 1-5: Word Biblical commentary. Vol. 52. Dallas: Word Books.

BARNARD, A.C. 1985. Die erediens. Pretoria: NG Kerkboekhandel.

BRIENEN, T. 1987. De liturgie bij Johannes Calvijn: zijn publikaties en zijn visies. Kampen: De Groot Goudriaan.

CALVIN, J. 1958. The four last books of Moses: in the form of a harmony. 2nd vol. Grand Rapids: Eerdmans.

CALVIN, J. 1965. Harmony of the evangelists Matthew, Mark and Luke. 3rd vol. Grand Rapids: Eerdmans.

COLE, R.D. 2000. Numbers: the new American commentary. Vol. 3B. Nashville: Broadman.

DAVIES, E.W. 1995. Numbers: new century Bible commentary. Grand Rapids: Eerdmans.

DE KLERK, B.J. \& JANSE VAN RENSBURG, J.J. 2005. Preekgeboorte: 'n handleiding vir gereformeerde eksegese en prediking. Toegepas op 1 Petrus 2:11-12, 18-25. Potchefstroom: Potchefstroomse Teologiese Publikasies.

FIORENZA, E.S. 2001. The words of prophecy: reading the Apocalypse theologically. (In Moyise, S. Studies in the book of Revelation. Edinburgh: Clark. p. 1-34.)

GARLAND, D.E. 1999. 2 Corinthians: Word Biblical commentary. Vol. 29. Dallas: Word Books.

GEREFORMEERDE KERKE VAN SUID-AFRIKA. 1985. Twee-en-veertigste Nasionale Sinode van die Gereformeerde Kerke in Suid-Afrika. Potchefstroom.

GEREFORMEERDE KERKE VAN SUID-AFRIKA. 1997. Ses-en-veertigste Nasionale Sinode van die Gereformeerde Kerke in Suid-Afrika. Potchefstroom.

GISPEN, W.H. 1950. Het boek Leviticus: commentaar op het Oude Testament. GKSA Kampen: Kok.

kyk GEREFORMEERDE KERKE VAN SUID-AFRIKA

GREIJDANUS, S. 1925. De openbaring des Heeren aan Johannes: kommentaar op het Nieuwe Testament. Amsterdam: Bottenburg.

GREIJDANUS, S. 1955. Het Evangelie naar Lukas: opnieuw uit den grondtekst vertaald en verklaard. Kampen: Kok. (Korte verklaring der Heilige Schrift.)

HARTLEY, J.E. 1992. Leviticus: Word Biblical commentary. Vol. 4. Dallas: Word Books.

HAWTHORNE, G.F. 1983. Philippians: Word Biblical commentary. Vol. 43. Dallas: Word Books.

JANSE VAN RENSBURG, J.J. 1999. Efesiërs: die Bybellennium. Eenvolumekommentaar: die Bybel uitgelê vir eietydse toepassing. Vereeniging: Christelike Uitgewersmaatskappy.

KAPIC, K.M. 2005. Receiving Christ's priestly benediction: a Biblical historical, and theological exploration of Luke 24:50-53. Westminister theological journal, 67(2):247-260. 
KORPEL, M.C.A. 1989. The poetic structure of the priestly blessing. Journal for the study of the Old Testament, 45:3-13.

LEVINE, B.A. 1993. Numbers: a new translation with introduction and commentary: the Ancor Bible. New York: Doubleday.

LOUW, J.P. \& NIDA, E.A. 1988. Greek-English lexicon of the New Testament based on semantic domains. Vol. 1: Introduction \& domains. New York: United Bible Societies.

MARTIN, R.P. 1986. 2 Corintians: Word Biblical commentary. Vol. 40. Dallas: Word Books.

McCANT, J.W. 1999. 2 Corinthians. Readings: a new Biblical commentary. Sheffield: Sheffield Academic.

MORTON, R. 2006. Book review of Ulrich Heckel's: Der Segen im Neuen Testament: Begriff; Formen, Gesten. Catholic Biblical quarterly, 68(3):543545.

NOLLAND, J. 1993. Luke 18:35-24:53: Word Biblical commentary. Vol. 35C. Dallas: Word Books.

NOORDTZIJ, A. 1957. Het boek Numeri: korte verklaring der Heilige Schrift. Kampen: Kok.

RIDDERBOS, H.N. 1959. Aan de Romeinen: commentaar op het Nieuwe Testament. Kampen: Kok.

RIDDERBOS, H.N. 1967. De pastorale brieven: commentaar op het Nieuwe Testament. Kampen: Kok.

ROOKER, M.F. 2000. Leviticus: the new American commentary. Vol. 3A. Nashville: Broadman \& Holman.

THRALL, M.E. 2004. The Second epistle to the Corinthians. Vol. 2. Commentary on 2 Corinthians 8-13: a critical and exegetical commentary. London: Clark.

VAN DE KAMP, G.C. 1998. Zegeningen. (In Oskamp, P. \& Schuman, N. De weg van de liturgie: tradities, achtergronden, praktijk. Zoetemeer: Meinema. p. 316-335.)

VAN LEEUEN, Th. M. 1998. Wegzending en zegen. (In Oskamp, P. \& Schuman, N. De weg van de liturgie: tradities, achtergronden, praktijk. Zoetemeer: Meinema. p. 257-265.)

VENTER, C.J.H. 1993. Basisteoretiese perspektiewe op kommunikasie in die bediening. In die Skriflig, 27(2):247-260.

VOS, C.J.A. \& PIETERSE, H.J.C. 1997. Hoe lieflik in u woning: studies in praktiese teologie. Pretoria: RGN.

WALHOUT, E. 2000. Revelation down to earth: making sense of the Apocalypse of John. Grand Rapids: Eerdmans.

WITHERINGTON III, B. 2003. Revelation. Cambridge: Cambridge University Press.

ZERFASS, R. 1974. Praktische Teologie als Handelungswissenschaft. (In Klostermann, F. \& Zerfass, R. Praktische Teologie Heute. München: Kaiser. S. 164-177.)

\section{Kernbegrippe:}

erediens

liturgie

seëngroet

wegstuurseën 


\section{Key concepts:}

liturgy

salutatory blessing

sending-away blessing

worship service 
